\title{
Publisher Correction: Insights from Earth system model initial-condition large ensembles and future prospects
}

\author{
C. Deser (D), F. Lehner (D), K. B. Rodgers, T. Ault, T. L. Delworth, P. N. DiNezio (D), A. Fiore (iD, C. Frankignoul, J. C. Fyfe (iD,

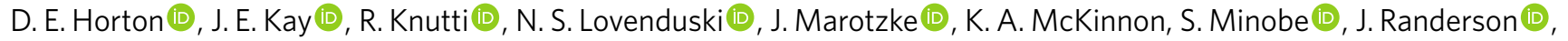 \\ J. A. Screen (D), I. R. Simpson (iD) and M. Ting (iD
}

Correction to: Nature Climate Change https://doi.org/10.1038/s41558-020-0731-2, published online 30 March 2020.

In the version of this Perspective originally published, in Fig. 4, the label "Computer skill score against $F_{\mathrm{LE}}$ and $I_{\mathrm{LE}}$ " in the blue circle was incorrect; it should have read "Compute skill score against $F_{\mathrm{LE}}$ and $I_{\mathrm{LE}}$ ". In refs. 30 and 59, the dois were incorrect and should have read https://doi.org/10.1175/JCLI-D-18-0882.1 and https://doi.org/10.5194/esd-2019-34, respectively. These errors have now been corrected in the online versions of the Perspective.

Published online: 26 June 2020

https://doi.org/10.1038/s41558-020-0854-5

๑) Springer Nature Limited 2020

\section{Publisher Correction: Vegetation feedbacks during drought exacerbate ozone air pollution extremes in Europe}

\author{
Meiyun Lin (D), Larry W. Horowitz (D), Yuanyu Xie (D), Fabien Paulot (D), Sergey Malyshev (D), Elena Shevliakova (D),
} Angelo Finco (D), Giacomo Gerosa (D), Dagmar Kubistin (iD and Kim Pilegaard (D)

Correction to: Nature Climate Change https://doi.org/10.1038/s41558-020-0743-y, published online 20 April 2020.

In the version of this Article originally published, in the label " $r^{2}(O B S, F I X D E P V)=0.6$ ” in the Fig. 5b legend, '0.6' was incorrect; instead, the label should have read " $r^{2}(O B S, F I X D E P V)=0.46$ ". This has now been corrected in the online versions.

Published online: 17 June 2020

https://doi.org/10.1038/s41558-020-0839-4

This is a U.S. government work and not under copyright protection in the U.S.; foreign copyright protection may apply 2020

\section{Publisher Correction: Projected shifts in the foraging habitat of crabeater seals along the Antarctic Peninsula}

Luis A. Hückstädt (D), Andrea Piñones, Daniel M. Palacios (D), Birgitte I. McDonald, Michael S. Dinniman (D),

Eileen E. Hofmann, Jennifer M. Burns (D), Daniel E. Crocker and Daniel P. Costa

Correction to: Nature Climate Change https://doi.org/10.1038/s41558-020-0745-9, published online 27 April 2020.

In this Article originally published, affiliation 1, "Department of Ecology and Evolutionary Biology, University of California, Santa Cruz, Santa Cruz, CA, USA" was incorrect and should have been "Institute of Marine Sciences, University of California, Santa Cruz, Santa Cruz, CA, USA". In addition, the following two affiliations were mistakenly not included: "Centro de Investigación Oceanográfica COPAS Sur-Austral, Universidad de Concepción, Concepción, Chile", which should have been associated with Andrea Piñones, and "Department of Ecology and Evolutionary Biology, University of California, Santa Cruz, Santa Cruz, CA, USA", which should have been associated with Daniel P. Costa. These affiliations have now been added, and other affiliations renumbered accordingly, in the online versions of the Article.

Published online: 24 June 2020

https://doi.org/10.1038/s41558-020-0850-9

(c) The Author(s), under exclusive licence to Springer Nature Limited 2020 